\title{
Problems faced by the trainees of Krishi Vigyan Kendra, Sonitpur in utilizing knowledge gained in the training programmes
}

\author{
Bitupan Borah ${ }^{1}$, Manindra Nath Ray ${ }^{1 *}$, Sadananda Payeng ${ }^{1}$, Leema Borah ${ }^{1}$, \\ Monosri Johari ${ }^{1}$, Bhrigu Kumar Neog ${ }^{2}$ and Shabnam Hazarika ${ }^{3}$ \\ ${ }^{1}$ Department of Extension Education College of Veterinary Science, AAU, Khanapara, India \\ ${ }^{2} K V K$, Sonitpur, India \\ ${ }^{3}$ Home Science, Handique Girls College, India \\ *Corresponding author
}

\section{A B S T R A C T}

\section{Keywords}

Training, Krishi

Vigyan Kendra,

Organized Market and RBQ

\section{Article Info}

Accepted:

22 February 2020

Available Online:

10 March 2020

A study was conducted in Krishi Vigyan Kendra, Sonitpur to assess the problems faced by the trainees in utilizing knowledge gained in training programme. The respondents were purposively selected from the three training programmes conducted by the Krishi Vigyan Kendra, Sonitpur, one each on dairy, goatery and poultry farming. As per the guidelines in every training programme under the KVK a minimum of 25 trainees consisting of farmer, farm women or rural youth should participate. Therefore it was thought prudent to cover 25 trainees from each of the three training programme to make the sample 75 . To fulfill the objectives of the study, data were collected through a pre-tested, reliable and valid interview schedule. The data thus collected were compiled, tabulated, processed and analyzed and organized according to the established standards and procedures and were subjected to appropriate statistical analysis in order to arrive at a conclusion. The ranking of constraints by key informants and trainees were ascertained by RBQ technique and the values of RBQ are presented in various tables. Inadequate capital (95.19) was assigned the first rank among all the constraints followed by "High rates of milch animal, chicks, improved breed of pigs and goats (80.76)", "Low purchasing capability (77.00)", "High cost of feed (70.19)", "Lack of loan facilities (69.43)", "Lack of supply of high yielder, improved breeds of goat, pig and poultry (56.43)", "small size land holding (53.76)", "Inability of the farmers to take risk in livestock entrepreneur (47.66)", "Lack of organized market and problems in marketing (39.09)", "Lack of breeding bull, boar and ram (38.38)", "Lack of A.I facilities (34.71)", "Irregular electricity (30.95)", "Inadequate grazing land (28.00)" and "Lack of land for fodder cultivation (27.00)". The value of Spearman's Rank correlation coefficient was found to be 0.97 which was highly significant at $0.1 \%$ level of significance.

\section{Introduction}

Efficient human resource at various levels is one of the important factors of development.
Due to the changing technological and economic scenario, the need for enhancing skills of development functionaries has been increasing daily. The competencies of various 
stakeholders involved in whole process of transfer of technology can be improved through well-organized training programmes, because training is a means to equip people to work efficiently in their present or future jobs. The scope of training is no longer confined only in developing knowledge and attitude. It has acquired new dimensions in organizational functioning, since considerable emphasis is placed on human resources in an organization.

Training having been recognized as an important tool of development, its scope and application are expanding increasingly. Now it is not only used in enhancing job related performance and organizational effectiveness. It is also being used in behavoural changes and in developing life skills the leads to personal growth. This is particularly true in a country like India, where more that $70 \%$ (Census, 2011) of the population live in rural areas. The rural people need to know about the technologies and innovations and develop their skills in different vocations for sustainable livelihood.

Therefore, in- service and vocational training are equally important for transfer of technologies with their common objective of rural development. Training is one of the mandatory activities of $\mathrm{KVK}$. It is evident that there is large financial involvement for conducting training programme under the KVK system, the ultimate objective of which is knowledge enhancement and skill development of the farmers.

In any extension approaches a varied number of teaching methods are applied to change the knowledge, attitude and practices (KAP). In the KVK system, training is one mandate in implementing which training programmes in different disciplines are conducted regularly with the obvious objective of disseminating knowledge to the trainees and developing their skills. In system approach of training a follow up action is vital in order to ensure that such training programmes help the trainees to utilize the knowledge gained in the training programme in their field proper. Further knowledge gain will be of little or no value unless and until it is put into practice by the gainers. There is every likelihood that in their attempt to utilize the gained knowledge in any training programme, multitudes of problems may appear, which need to be addressed by appropriate authority in proper time.

\section{Materials and Methods}

The respondents were purposively selected from the three training programmes conducted by the Krishi Vigyan Kendra, Sonitpur, one each on dairy, goatery and poultry farming. As per the guidelines in every training programme under the KVK a minimum of 25 trainees consisting of farmer, farm women or rural youth should participate.

Therefore it was thought prudent to cover 25 trainees from each of the three training programme to make the sample 75. After receiving necessary permission from the Directorate of Extension Education, AAU, Jorhat the researchers proceeded with the work along with the concerned K.V.K. officials with whom regular contacts were being made by the researcher to get to know beforehand the time and date of the training programmes on livestock and poultry that were enlisted in the action plan.

The data for the present study were collected by researchers using the interview method. The pre training evaluation was conducted before the training programme at convenient places and the post training evaluation was conducted after the training programmes at the training hall of K. V. K, Sonitpur or at their houses on the next day. The second phase of data collection was undertaken by 
the researcher personally who, fixed some appointment with the respondents and collected the data through the interview schedule at their residence at convenient hours of the day. Each respondent was contacted separately and individually. The responses obtained from the respondents were recorded immediately on the interview schedule.

The interviews were conducted during the month of February till April, 2018 covering all the respondents who had undergone the training programme conducted in $\mathrm{K}$. V. K, Sonitpur. Rank Based Quotient (RBQ) 10) Spearman's rank correlation was used in statistical analysis. The ranking of constraints by key informants and trainees were ascertained by RBQ technique and the values of RBQ are presented in various tables under the following sub-heads

\section{Results and Discussion}

The ranking of constraints by key informants and trainees were ascertained by RBQ technique and the values of RBQ are presented in various tables under the following sub-heads. Based on the mean RBQ Values as depicted in Table1, "Inadequate capital" (95.19) was assigned the first rank among all the constraints followed by "High rates of milch animal, chicks, improved breed of pigs and goats (80.76)", "Low purchasing capability (77.00)", "High cost of feed (70.19)", "Lack of loan facilities (69.43)", "Lack of supply of high yielder, improved breeds of goat, pig and poultry (56.43)", "small size land holding (53.76)", "Inability of the farmers to take risk in livestock entrepreneur (47.66)", "Lack of organized market and problems in marketing (39.09)", "Lack of breeding bull, boar and ram (38.38)", "Lack of A.I facilities (34.71)", "Irregular electricity (30.95)", "Inadequate grazing land (28.00)" and "Lack of land for fodder cultivation (27.00)". The value of Spearman's Rank correlation coefficient was found to be 0.97 which was highly significant at $0.1 \%$ level of significance. This adequately implied that there was a strong association between the perception of the Key Informants and the respondents of the study area in respect of their feeling about constraints encountered at the time of utilizing knowledge gained in the training programme.

It has been evident from the above that in constant analysis "Inadequate capital" was ranked as the most important constraint by the respondents. In the present scenario, capital which is one of the major components of business establishment receives top most priority from the entrepreneurs. The respondents with their traditional cultivation along with livestock and poultry keeping cannot accumulate any surplus which could be used as capital in future.

Therefore the topmost priority accorded by the respondents to this factor is easily understandable. This finding is in line with the findings of Singh et al., (2015) and Singh et al., (2018). The second important constraint was found to be "High rates of milch animal, chicks, improved breed of pigs and goats". This is due to the fact that the breeding farms in the state are very less in number, which is obviously the cause of shortage of breeding stock in the state and also their resultant high price. Therefore the interested farmers might have suffered from such shortfall and hence their feeling was only justified. The third important constraint was found to be "Low purchasing capability".

This might be due to the practices they follow like monoculture cropping which in turn had low income generation and the traditional methods of farming. The subsistence livelihood of the respondent is the root cost of their low purchasing capability. This finding 
is in line with the findings of Suchiang et al., (2016). "High cost of feed" was identified as the fourth important constraint faced by the respondents. This is due to the fact that 70.00 per cent of the total cost in any livestock farming is incurred for feed. Therefore, expenditure of the feed is a cause of major concern for the farmers. The ingredients of the livestock feed are not commercially grown in Assam and hence are imported from outside the state.

Therefore, it is only natural that sky rocketing price of the feed has inhibited the interested farmers in their farming venture. This finding is in line with the findings of Singh et al., (2015) and Suchiang et al., (2016). "Lack of loan facilities" was identified as the fifth important constraint. The absence of credit facilities for the farming community is a great hindrance for livestock entrepreneurship development. The process of loan disbursement to the farmers is cumbersome and tedious. In this connection it needs to be mentioned that non-performing assets (NPA) of the banks and other financial institutions are fast growing throughout the country forcing the concerned authorities to make more stringent rules and regulations for such loans.

This is more true in the case of the farmers. Therefore under the prevailing situation the farmers seeking loan for livestock enterprises are subjected to some sort of harassment due to the rules and regulation. Hence the weight age given on such constraint is only relevant. This finding is similar to the findings of Suchiang et al., (2016). "Lack of supply of high yielder, improved breeds of goat, pig and poultry", was ranked as the sixth constraint.

It has already been mentioned that absence of breeding farms in both public and private sector in the state has become a major hindrance for the farmers in procuring quality breeding stocks. Moreover under the prevailing policy of the market economy the government does not have adequate programmes and schemes to distribute such breeding stocks to the farmers free of cost. Therefore their perception is understandable. "Small size land holding", was identified as the seventh important constraint faced by the respondents. Population explosion which is more rampant in India and the preference for nuclear families in the modern society are causes of increased number of household necessitating the division of the parental land holding making their size smaller. The farmers with smaller land holdings find it increasingly difficult to go for mechanization and mixed farming. As such they perceived it as a constraint.

"Inability of the farmers to take risk in livestock entrepreneur", was identified as the eighth important constraint among the respondents. The frequently occurring natural calamities due to global warming, climate change and other man-made devastations are the causes of apprehension among the farmers who foresee the dire consequences of risk taking. The growing number of farmer suicide throughout the country which very often makes headlines in the media reinforces the apprehension of the farmers. Therefore they declined to take any risk. This finding is similar to the findings of Phukan et al., (2017).

"Lack of organized market and problems in marketing", was ranked as the ninth constraint faced by the respondents. During the research study it was found that the respondents were mainly from the remote areas and there was no proper organized market for selling their livestock products. Thus they could not fetch good amount from the products in return. Hence they feel the need of organized market. The finding is similar with the findings of Singh et al., (2018) and Johari et al., (2014). 
Table.1 Ranking Of Constrains By Key Informants In K.V.K, Sonitpur

\begin{tabular}{|c|c|c|c|c|c|c|c|c|c|c|c|c|c|c|c|c|}
\hline \multirow[b]{2}{*}{$\begin{array}{l}\text { Constraints } \\
(\mathrm{N}=15)^{*}\end{array}$} & \multicolumn{14}{|c|}{ RANK } & \multirow[b]{2}{*}{ Total } & \multirow{2}{*}{$\begin{array}{c}\text { Rank } \\
\text { Based } \\
\text { Quotien } \\
\text { (RBQ) }\end{array}$} \\
\hline & I & II & III & IV & $\mathrm{V}$ & VI & VII & VIII & IX & $\mathrm{X}$ & $\mathrm{XI}$ & XII & XIII & XIV & & \\
\hline Inadequate capital & 112 & 42 & 14 & 0 & 0 & 0 & 0 & 0 & 0 & 0 & 0 & 0 & 28 & 14 & 202 & 96.19 \\
\hline $\begin{array}{l}\text { High rates of milch animal, } \\
\text { chicks, improved } \\
\text { breed of pigs and goats }\end{array}$ & 12 & 60 & 0 & 48 & 24 & 0 & 0 & 0 & 36 & 0 & 0 & 0 & 0 & 0 & 167 & 79.52 \\
\hline Low purchasing capability & 78 & 13 & 52 & 13 & 0 & 0 & 0 & 0 & 0 & 0 & 0 & 13 & 26 & 0 & 165 & 78.57 \\
\hline Lack of loan facilities & 0 & 0 & 66 & 11 & 33 & 0 & 22 & 0 & 0 & 0 & 0 & 0 & 0 & 33 & 149 & 70.95 \\
\hline High cost of feed & 0 & 10 & 10 & 40 & 60 & 0 & 20 & 0 & 10 & 0 & 0 & 0 & 0 & 0 & 147 & 70.00 \\
\hline $\begin{array}{l}\text { Lack of supply of high } \\
\text { yielder, improved } \\
\text { breeds of goat, pig and } \\
\text { poultry }\end{array}$ & 0 & 0 & 16 & 16 & 8 & 16 & 16 & 8 & 24 & 8 & 0 & 0 & 0 & 8 & 126 & 60.00 \\
\hline small size land holding & 0 & 0 & 0 & 0 & 6 & 0 & 12 & 30 & 18 & 6 & 0 & 6 & 0 & 12 & 108 & 51.43 \\
\hline $\begin{array}{l}\text { Inability of the farmers to } \\
\text { take risk in } \\
\text { livestock entrepreneur }\end{array}$ & 0 & 0 & 0 & 0 & 0 & 0 & 0 & 0 & 1 & 2 & 2 & 0 & 10 & 0 & 95 & 45.24 \\
\hline $\begin{array}{l}\text { Lack of breeding bull, boar } \\
\text { and ram }\end{array}$ & 0 & 0 & 0 & 0 & 7 & 28 & 7 & 14 & 0 & 0 & 14 & 35 & 0 & 0 & 83 & 39.52 \\
\hline Lack of A.I facilities & 0 & 36 & 9 & 18 & 9 & 0 & 45 & 0 & 9 & 0 & 0 & 0 & 0 & 9 & 81 & 38.57 \\
\hline $\begin{array}{l}\text { Lack of organized market } \\
\text { and } \\
\text { problems in marketing }\end{array}$ & 0 & 0 & 0 & 3 & 0 & 0 & 0 & 0 & 3 & 9 & 12 & 3 & 0 & 15 & 76 & 36.19 \\
\hline Irregular electricity & 0 & 0 & 0 & 0 & 0 & 2 & 0 & 2 & 2 & 4 & 4 & 10 & 2 & 4 & 66 & 31.43 \\
\hline Inadequate grazing land & 0 & 0 & 0 & 0 & 0 & 15 & 0 & 25 & 5 & $\begin{array}{l}2 \\
5\end{array}$ & 0 & 5 & 0 & 0 & 58 & 27.62 \\
\hline $\begin{array}{l}\text { Lack of land for fodder } \\
\text { cultivation }\end{array}$ & 0 & 4 & 0 & $\mathbf{0}$ & 0 & 20 & 4 & 4 & 0 & 4 & 20 & 4 & 0 & $\mathbf{0}$ & 52 & 24.76 \\
\hline
\end{tabular}


Table.2 Ranking Of Constraints by Respondents In K.V.K, Sonitpur

\begin{tabular}{|c|c|c|c|c|c|c|c|c|c|c|c|c|c|c|c|c|}
\hline \multirow[b]{2}{*}{ Constraints $(\mathrm{N}=75)^{*}$} & \multicolumn{14}{|c|}{ RANK } & \multirow[b]{2}{*}{ Total } & \multirow{2}{*}{$\begin{array}{l}\text { Rank } \\
\text { Based } \\
\text { Quotient } \\
\text { (RBQ) }\end{array}$} \\
\hline & I & II & III & IV & V & VI & VII & VIII & IX & $\mathrm{X}$ & $\mathrm{XI}$ & $\begin{array}{l}\text { X } \\
\text { I } \\
\text { I }\end{array}$ & $\begin{array}{c}\mathrm{X} \\
\text { II } \\
\text { I }\end{array}$ & $\begin{array}{c}\text { X } \\
\text { I } \\
\text { V }\end{array}$ & & \\
\hline Inadequate capital & 630 & 195 & 36 & 88 & 40 & 0 & 0 & 0 & 0 & 0 & 0 & 0 & 0 & 0 & 989 & 94.19 \\
\hline $\begin{array}{l}\text { High rate of milch animal, } \\
\text { chicks, improved breed of pigs } \\
\text { and goats }\end{array}$ & 112 & 234 & 120 & 253 & 40 & 54 & 48 & 0 & 0 & 0 & 0 & 0 & 0 & 0 & 861 & 82.00 \\
\hline Low purchasing capability & 56 & 143 & 192 & 121 & 130 & 108 & 16 & 0 & 0 & $\begin{array}{l}1 \\
0\end{array}$ & 16 & 0 & 0 & 0 & 792 & 75.43 \\
\hline High cost of feed & 0 & 91 & 96 & 121 & 280 & 81 & 24 & 7 & 18 & 5 & 16 & 0 & 0 & 0 & 739 & 70.38 \\
\hline Lack of loan facilities & 0 & 26 & 240 & 44 & 120 & 117 & 128 & 14 & 12 & 0 & 0 & $\begin{array}{l}1 \\
2\end{array}$ & 0 & 0 & 713 & 67.90 \\
\hline $\begin{array}{l}\text { Lack of supply of high yielder, } \\
\text { improved breeds of goat, pig } \\
\text { and poultry }\end{array}$ & 42 & 0 & 0 & 55 & 100 & 207 & 24 & 63 & 60 & $\begin{array}{l}1 \\
5\end{array}$ & 24 & 3 & 4 & 0 & 597 & 56.86 \\
\hline small size land holding & 0 & 65 & 216 & 11 & 20 & 72 & 104 & 7 & 42 & $\begin{array}{l}2 \\
0\end{array}$ & 16 & 3 & 4 & 9 & 589 & 56.09 \\
\hline $\begin{array}{l}\text { Inability of the farmers to take } \\
\text { risk in livestock entrepreneur }\end{array}$ & 70 & 78 & 0 & 99 & 0 & 18 & 32 & 98 & 48 & 5 & 20 & $\begin{array}{l}4 \\
8\end{array}$ & $\begin{array}{l}1 \\
0\end{array}$ & 0 & 526 & 50.09 \\
\hline $\begin{array}{l}\text { Lack of organized market } \\
\text { and problems in marketing }\end{array}$ & 0 & 91 & 0 & 0 & 0 & 0 & 72 & 133 & 48 & $\begin{array}{l}2 \\
5\end{array}$ & 16 & $\begin{array}{l}3 \\
0\end{array}$ & $\begin{array}{l}2 \\
6\end{array}$ & 0 & 441 & 42.00 \\
\hline $\begin{array}{l}\text { Lack of breeding bull, boar and } \\
\text { ram }\end{array}$ & 0 & 0 & 0 & 11 & 0 & 18 & 48 & 14 & 120 & $\begin{array}{l}1 \\
2 \\
0\end{array}$ & 24 & $\begin{array}{l}2 \\
4\end{array}$ & $\begin{array}{l}1 \\
2\end{array}$ & 0 & 391 & 37.24 \\
\hline Lack of A.I facilities & 0 & 0 & 0 & 0 & 0 & 0 & 32 & 70 & 18 & $\begin{array}{l}8 \\
5\end{array}$ & 76 & $\begin{array}{l}1 \\
2\end{array}$ & $\begin{array}{l}2 \\
6\end{array}$ & 5 & 324 & 30.86 \\
\hline Irregular electricity & 140 & 52 & 0 & 0 & 0 & 0 & 0 & 7 & 30 & $\begin{array}{l}2 \\
0\end{array}$ & 16 & 6 & 8 & $\begin{array}{l}4 \\
1\end{array}$ & 320 & 30.47 \\
\hline Inadequate grazing land & 0 & 0 & 0 & 22 & 0 & 0 & 32 & 42 & 36 & $\begin{array}{l}5 \\
5\end{array}$ & 28 & $\begin{array}{l}3 \\
9\end{array}$ & $\begin{array}{l}3 \\
6\end{array}$ & 8 & 298 & 28.38 \\
\hline $\begin{array}{l}\text { Lack of land for fodder } \\
\text { cultivation }\end{array}$ & $\mathbf{0}$ & 13 & $\mathbf{0}$ & $\mathbf{0}$ & 20 & $\mathbf{0}$ & 40 & 70 & 24 & $\begin{array}{l}1 \\
5\end{array}$ & 44 & $\begin{array}{l}4 \\
5\end{array}$ & $\begin{array}{l}2 \\
4\end{array}$ & $\begin{array}{l}1 \\
2\end{array}$ & 307 & 29.24 \\
\hline
\end{tabular}


Table.3 Preferential Ranking Based On Mean Values Of R.B.Q Of Both Key Informants And Respondents In Krishi Vigyan Kendra, Sonitpur

\begin{tabular}{|c|c|c|c|c|}
\hline CONSTRAINTS & $\begin{array}{l}\text { RBQ Values } \\
\text { (KI) }\end{array}$ & $\begin{array}{l}\text { RBQ Values } \\
\text { (Respondents) }\end{array}$ & $\begin{array}{l}\text { Mean } \\
\text { R.B.Q }\end{array}$ & $\begin{array}{l}\text { Preferential } \\
\text { Ranking }\end{array}$ \\
\hline Inadequate capital & 94.19 & 96.19 & 95.19 & I \\
\hline $\begin{array}{l}\text { High rates of milch } \\
\text { animal, chicks, improved } \\
\text { breed of pigs and goats }\end{array}$ & 82.00 & 79.52 & 80.76 & II \\
\hline Low purchasing capability & 75.43 & 78.57 & 77.00 & III \\
\hline High cost of feeds & 70.38 & 70.00 & 70.19 & IV \\
\hline Lack of loan facilities & 67.90 & 70.95 & 69.43 & $\mathbf{V}$ \\
\hline $\begin{array}{l}\text { Lack of supply of high } \\
\text { yielder, improved breeds } \\
\text { of goat, pig and poultry }\end{array}$ & 56.86 & 60.00 & 58.43 & VI \\
\hline Small size land holding & 56.09 & 51.43 & 53.76 & VII \\
\hline $\begin{array}{l}\text { Inability of the } \\
\text { farmers to take risk in } \\
\text { livestock entrepreneur }\end{array}$ & 50.09 & 45.24 & 47.66 & VIII \\
\hline $\begin{array}{l}\text { Lack of organized market } \\
\text { and problems in marketing }\end{array}$ & 42.00 & 36.19 & 39.09 & IX \\
\hline $\begin{array}{l}\text { Lack of breeding bull, } \\
\text { boar and ram }\end{array}$ & 37.24 & 39.52 & 38.38 & $\mathbf{X}$ \\
\hline Lack of A.I facilities & 30.86 & 38.57 & 34.71 & $\mathbf{X I}$ \\
\hline Irregular electricity & 30.47 & 31.43 & 30.95 & XII \\
\hline Inadequate grazing land & 28.38 & 27.62 & 28.00 & XIII \\
\hline $\begin{array}{l}\text { Lack of land for } \\
\text { fodder cultivation }\end{array}$ & 29.24 & 24.76 & 27.00 & XIV \\
\hline
\end{tabular}


Table.4 Spearman's rank correlation co-efficient between constraints perceived by key informants and respondents in krishi vigyan kendra, sonitpur

\begin{tabular}{|c|c|c|c|c|c|c|}
\hline CONSTRAINTS & $\begin{array}{l}\text { RBQ } \\
\text { Values (KI) }\end{array}$ & Rank & $\begin{array}{l}\text { RBQ Values } \\
\text { (Respondents) }\end{array}$ & Rank & D & $\mathrm{Di}^{2}$ \\
\hline Inadequate capital & 94.19 & 1 & 96.19 & 1 & 0 & $\mathbf{0}$ \\
\hline $\begin{array}{l}\text { High rates of milch } \\
\text { animal, chicks, improved } \\
\text { breed of pigs and goats }\end{array}$ & 82.00 & 2 & 79.52 & 2 & 0 & $\mathbf{0}$ \\
\hline $\begin{array}{l}\text { Low purchasing } \\
\text { capability }\end{array}$ & 75.43 & 3 & 78.57 & 3 & 0 & $\mathbf{0}$ \\
\hline High cost of feeds & 70.38 & 5 & 70.00 & 4 & -1 & 1 \\
\hline Lack of loan facilities & 67.90 & 4 & 70.95 & 5 & 1 & 1 \\
\hline $\begin{array}{l}\text { Lack of supply of high } \\
\text { yielder, improved } \\
\text { breeds of goat, pig and } \\
\text { poultry }\end{array}$ & 56.86 & 6 & 60.00 & 6 & 0 & $\mathbf{0}$ \\
\hline Small size land holding & 56.09 & 7 & 51.43 & 7 & 0 & $\mathbf{0}$ \\
\hline $\begin{array}{l}\text { Inability of the } \\
\text { farmers to take risk } \\
\text { in livestock } \\
\text { entrepreneur }\end{array}$ & 50.09 & 8 & 45.24 & 8 & 0 & $\mathbf{0}$ \\
\hline $\begin{array}{l}\text { Lack of organized } \\
\text { market and problems in } \\
\text { marketing }\end{array}$ & 42.00 & 11 & 36.19 & 9 & -2 & 4 \\
\hline $\begin{array}{l}\text { Lack of breeding bull, } \\
\text { boar and ram }\end{array}$ & 37.24 & 9 & 39.52 & 10 & 1 & 1 \\
\hline Lack of A.I facilities & 30.86 & 10 & 38.57 & 11 & 1 & 1 \\
\hline Irregular electricity & 30.47 & 12 & 31.43 & 12 & 0 & $\mathbf{0}$ \\
\hline Inadequate grazing land & 28.38 & 13 & 27.62 & 14 & 1 & 1 \\
\hline $\begin{array}{l}\text { Lack of land for } \\
\text { fodder cultivation }\end{array}$ & 29.24 & 14 & 24.76 & 13 & -1 & 1 \\
\hline \multicolumn{6}{|c|}{$\mathrm{R}=0.97$} & $\sum \mathbf{1 0}$ \\
\hline
\end{tabular}


"Lack of breeding bull, boar and ram", was ranked as the tenth constraint faced by the respondents. In establishing a farm they required good breeding bull, boar and ram for better off-springs for next generation. But this was lacking in their place and they had to transport their animals to a long distance during the time of estrous for natural service. Similar findings were also found by Patra et al., (2014).

"Lack of A.I facilities", was another important constraint faced by the respondents and it was ranked in number eleventh. For increasing the production, cross bred animals are mostly preferred. This can be obtained by artificial insemination.

Although the state government has taken up the steps for production of semen straw but their availability in the field is very low. So the farmers are not easily accessible to it. This finding is similar with the findings of Singh et al., (2015). "Irregular electricity", was identified as the twelfth important constraint among the respondents.

Although electricity connection is available in each and every house hold but the regular disruption of electric supply is a severe problem for all sections of the society. To start up poultry farm electricity is most essential for better production. Since there is interruption of supply of electricity every day they face difficulty in management of the farm. "Inadequate grazing land", was assigned as the thirteenth constraint.

Due to the over increasing population now a days, the barren lands in the villages are fast disappearing. Moreover the village grazing reserve and community grazing reserve, which were used for livestock grazing, have been used for human settlement. Thus inadequacy of grazing land in the rural area has become a widely perceived problem among the farmers. This finding was totally corroborated by Singh et al., (2018) who found that lack of grazing land as the major constraint in their study. "Lack of land for fodder cultivation", was ranked as the fourteenth constraint faced by the respondents.

As it has been evident that the disappearance of barren land, village grazing reserve and community grazing reserve had created a situation where the farmers need to cultivate fodders at their own but for that purpose also they did not have adequate land. This led the farmers in a quandary.

Hence, their feelings are in right direction. Based on the mean RBQ Values as depicted in Table 3, "Inadequate capital" (95.19) was assigned the first rank among all the constraints followed by "High rates of milch animal, chicks, improved breed of pigs and goats (80.76)", "Low purchasing capability (77.00)", "High cost of feed (70.19)", "Lack of loan facilities (69.43)", "Lack of supply of high yielder, improved breeds of goat, pig and poultry (56.43)", "small size land holding (53.76)", "Inability of the farmers to take risk in livestock entrepreneur (47.66)", "Lack of organized market and problems in marketing (39.09)", "Lack of breeding bull, boar and ram (38.38), Lack of AI facilities (34.71), Irregular electricity(20.95), Inadequate grazing land (28.00) and Lack of land for fodder cultivation (27.00).

As depicted in Table 4, the Rank correlation coefficient was found to be 0.97 which was highly significant at $0.1 \%$ level of significance. This indicates that there is a very close association between perception of the Key Informants (KI) and that of the respondents with regard to the constraints faced by the trainees/respondents in utilizing the knowledge gained in the training programmes. 


\section{Acknowledgement}

The research team is acknowledged to the Head, Department of Extension Education, College of Veterinary Science, AAU, Khanapara and Dr. P.C. Deka, Senior Scientist cum Head, Krishi Vigyan Kendra Sonitpur.

\section{References}

Johari, M.; Sharia. K. K.; Bora, L.; Roychoudhury, R. and Khuman, S. L. (2014). Problems faced by pig farmers in Dima Hasao district of Assam. J. Krishi Vigyan, 2(2):59-63.

Patra, M.K.; Begum, S. and Deka, B.C. (2014). Problems and Prospects of Traditional Pig Farming for Tribal Livelihood in Nagaland. Indian Research Journal of Extension Education, 14(4).
Phukan, P.; Lepcha, B. and Avasthe, R. (2017). Impact of training programmes on adoption of organic farming practices with organic marketing in East Sikkim. Indian Res. J. Ext. Edu., 17(4).

Pyrtuh, R. (2016). Progressive poultry rearing ventures in selected districts of Meghalaya. M.V.Sc. Thesis (unpublished), Assam Agricultural University, Khanapara, Guwahati, Assam.

Singh, D.; Kerketta, P.; Kumar, A. and Neeraj (2018). Constraints in goat and sheep husbandry practices in Allahabad districts of Uttar Pradesh, India. Journal of Pharmacognosy and Phytochemistry, 7(2). Singh, P.; Bhatti, J. S.; Hundal, J. S. and Kansal, K. S. (2015). Constraints faced by farmers in adoption of dairy as entrepreneurship. Haryana Vet., 54(1):67-69.

\section{How to cite this article:}

Bitupan Borah, Manindra Nath Ray, Sadananda Payeng, Leema Borah, Monosri Johari, Bhrigu Kumar Neog and Shabnam Hazarika. 2020. Problems faced by the trainees of Krishi Vigyan Kendra, Sonitpur in utilizing knowledge gained in the training programmes. Int.J.Curr.Microbiol.App.Sci. 9(03): 2933-2942. doi: https://doi.org/10.20546/ijcmas.2020.903.337 